J. Perinat. Med. 14 (1986) 59

\section{Simultaneous investigations of maternal cardiac output and fetal blood flow during hypervolemic hemodilution in preeclampsia - preliminary observations}

\author{
Ulrich Siekmann¹, Lothar Heilmann'1, Wolfgang Klosa ${ }^{2}$, Ludwig Quaas ${ }^{2}$, and \\ Helmut Schillinger ${ }^{2}$
}

${ }^{1}$ Department of Obstetrics and Gynecology, University of Essen, and ${ }^{2}$ Department of Obstetrics and Gynecology I, University of Freiburg, Fed. Rep. Germany

\section{Introduction}

Since the occurrence of plasma volume depletion represents a typical pathophysiological feature in preeclampsia $[5,7,10]$, several groups have demonstrated favorable results in the treatment with plasma volume expanders $[4,6$, $8,9,18,19,20,22]$.

During hypervolemic hemodilution with low molecular dextran, both SCHWARZ and RETZKE [19] and CLOEREN et al. [4] described increased impulse rates using isotope techniques as an index of elevated placental perfusion. In contrast, Jouppila et al. [12] estimated no improvement of placental perfusion in the course of a $100 \mathrm{ml}$ infusion of $20 \%$ human albumin.

For the early detection of heart decompensation attributed to fluid overload during plasma expander therapy intensive surveillance is recommended [4]. In previous studies [22] we could demonstrate that alterations in maternal cardiac output as well as the fluid intake in the lungs can be continuously monitored by means of noninvasive thoracic impedance cardiography.

The interest in developing noninvasive methods for fetal blood flow measurements has gradually increased. Meanwhile pulsed doppler ultrasonography offers the possibility of estimating

\section{Curriculum vitae}

U. SIEKmann, $M$. D., was born in 1950. Since 1978 he has been working as an Assistant at the University in Essen, Department of Obstetrics and Gynecology. Main fields of interest: $\mathrm{ma}$ ternal and fetal hemodynamics in pregnancy, blood flow behavior in complicated pregnancies, ultrasound.

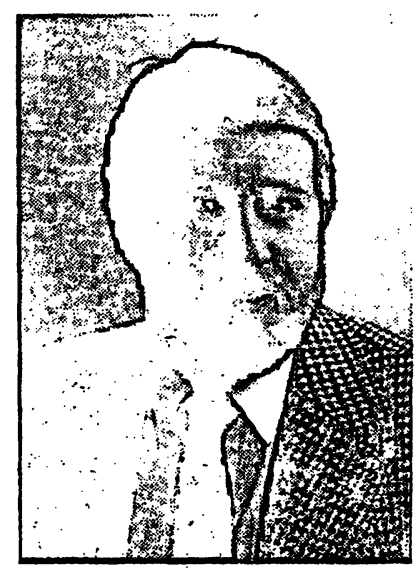

data on fetal blood flow characteristics $[3,11$, 14].

The subject of the following investigation was to combine both thoracic impedance cardiography and pulsed doppler ultrasonography for the simultaneous noninvasive estimation of maternal and fetal hemodynamics during hypervolemic hemodilution in preeclampsia. In humans the simultaneous monitoring of both hemodynamic systems has not been focused as yet.

\section{Material and methods}

This preliminary report summarizes the investigations in five preeclamptic women in the last 
Table I. Characteristics of patients in study.

\begin{tabular}{lllllll}
\hline Init. & $\begin{array}{l}\text { Age } \\
(\mathrm{yrs})\end{array}$ & $\begin{array}{l}\text { Gest. Age } \\
(\mathrm{wks} / \mathrm{d})\end{array}$ & $\begin{array}{l}\text { Weight } \\
(\mathrm{kg})\end{array}$ & $\begin{array}{l}\text { Body surface } \\
\left(\mathrm{m}^{2}\right)\end{array}$ & $\begin{array}{l}\text { MAP } \\
(\mathrm{mm} \mathbf{H g})\end{array}$ & $\begin{array}{l}\text { Fet. weight } \\
(\mathrm{gr} .)\end{array}$ \\
\hline S. B. & 19 & $37 / 1$ & 69 & 1.66 & 106.7 & 1500 \\
S-M. A. & 21 & $36 / 6$ & 98 & 2.09 & 108.3 & 2450 \\
F. R. & 22 & $38 / 6$ & 69 & 1.79 & 110.0 & 3300 \\
B. M. & 23 & $38 / 6$ & 76 & 1.86 & 103.3 & 2600 \\
M.F. & 21 & $39 / 4$ & 74 & 1.74 & 106.7 & 3040 \\
\hline
\end{tabular}

trimester of pregnancy. All patients were admitted to hospital care with raised mean arterial blood pressure (MAP > $103.3 \mathrm{~mm} \mathrm{Hg}$ ) and hemoconcentration (hematocrit $>38 \%$ ). The ultrasonographic estimation of the fetus in all cases showed no anatomical malformations. Patients' characteristics are summarized in table I.

The antenatal fetal weight was estimated according to the chest and head circumferences. All patients were without any antihypertensive drug treatment or diuretics. The basic treatment consisted of bed rest prior to hypervolemic hemodilution. Informed consent was obtained from all patients, who were included in this study.

\subsection{Clinical procedure}

Hypervolemic hemodilution was performed with $500 \mathrm{ml}$ low molecular dextran* intravenously over a period of exactly 60 minutes. Twenty $\mathrm{ml}$ of hapten** was preinjected to avoid anaphylactic reactions.

Twentyfour hours after dextran application the same patients received $500 \mathrm{ml}$ physiologic saline solution using the same conditions compared to hypervolemic hemodilution with dextran. This placebo-controlled procedure in intraindividual comparison was performed to distinguish between specific dextran effects and nonspecific effects of isovolemic hemodilution with $\mathrm{NaCl}$ on the maternal and fetal circulatory system.

\footnotetext{
* Rheomakrodex ${ }^{\oplus},{ }^{* *}$ Promit $^{\circledR}$, Marketing: Knoll AG,
} Ludwigshafen, FRG
During dextran and $\mathrm{NaCl}$ supply, the following hemodynamic parameters were monitored in 15-minutes intervals:

maternal: heart rate, blood pressure, stroke volume, cardiac output (calculated as cardiac index);

fetal: heart rate, flow velocity and flow volume in the descending aorta and umbilical vein.

In the following 60-minutes period after the end of infusion these measurements were repeated at 15 minutes ( $p 15), 30$ minutes ( $p$ 30) and 60 minutes ( $p$ 60). In each patient a total of eight measurements were carried out for both dilution regimen. All hemodilutions were performed at the same daytime (afternoon) to avoid possible undesired side effects due to maternal and fetal circadian rhythm.

\subsection{Technical equipment}

Maternal hemodynamics: We used the IFM Impedance Cardiograph, model 400*. ECG, phonocardiogram, the impedance signal delta $\mathrm{Z}$ and its first derivate $\mathrm{dZ} / \mathrm{dt}$ were recorded via a multichannel plotter. Beat-to-beat calculations of isolated stroke volume and the cardiac output were estimated with a built-in ZCGComputer*. This computer was triggered by two potentiometers, which indicate the respective distances of the internal electrode bands and the specific hematocrit-dependent resistance of blood [15]. Heart rate was derived from the ECG-recordings.

\footnotetext{
* Marketing: Diefenbach GmbH, Frankfurt, FRG
} 
Table ll. Summary of maternal hemodynamic parameters during dextran 40 and $\mathrm{NaCl}$ supply.

Mcan values + standard deviation ( $)^{*}=\mathrm{p}<0.05$ (in relation to the respective value prior to infusion).

I. Dextran 40

\begin{tabular}{lllllllll}
\hline Parameter & $\begin{array}{l}\text { prior to } \\
\text { infusion }\end{array}$ & $\begin{array}{l}15 \\
\text { Time } \\
(\mathrm{min})\end{array}$ & 30 & 45 & 60 & $\mathrm{p} 15$ & $\mathrm{p} 30$ & $\mathrm{p} 60$ \\
\hline $\begin{array}{l}\text { Heart rate } \\
\text { (bts/min) }\end{array}$ & $85(10)$ & $78(12)$ & $82(8)$ & $81(9)$ & $87(11)$ & $82(7)$ & $81(8)$ & $80(9)$ \\
$\begin{array}{l}\text { Stroke volume } \\
\text { (ml) }\end{array}$ & $69.9(18)$ & $* 79.4(19)$ & $76.9(17)$ & $* 83.6(22)$ & $80.4(25)$ & $* 79.9(18)$ & $* 79.5(19)$ & $* 79.3(20)$ \\
$\begin{array}{l}\text { Cardiac Index } \\
\left(\mathrm{L} / \mathrm{min}, \mathrm{m}^{2}\right)\end{array}$ & $3.20(0.87)$ & $3.62(1.04)$ & $3.96(1.44)$ & $* 4.25(1.50)$ & $* 4.22(1.23) * 4.11(1.20) * 3.86(1.19) * 3.59(0.90)$ \\
\hline
\end{tabular}

II. $\mathrm{NaCl}$

\begin{tabular}{lllllllll}
\hline $\begin{array}{l}\text { Heart ratc } \\
\text { (bts/min) }\end{array}$ & $89(11)$ & $87(11)$ & $87(12)$ & $86(8)$ & $85(2)$ & $84(11)$ & $82(9)$ & $87(11)$ \\
$\begin{array}{l}\text { Strokc volume } \\
(\mathrm{ml})\end{array}$ & $63.0(16)$ & $67.0(19)$ & $67.9(20)$ & $72.9(16)$ & $66.9(16)$ & $70.7(16)$ & $72.2(14)$ & $68.7(15)$ \\
$\begin{array}{l}\text { Cardiac Index } \\
\left(\mathrm{L} / \mathrm{min}, \mathrm{m}^{2}\right)\end{array}$ & $3.20(0.70)$ & $3.29(0.80)$ & $3.24(0.90)$ & $3.34(0.76)$ & $3.20(0.70)$ & $3.15(0.66)$ & $3.21(0.59)$ & $3.15(0.50)$ \\
\hline
\end{tabular}

Fetal hemodynamics: Simultaneously to maternal hemodynamic monitoring we investigated fetal blood flow characteristics, using an ADR Kranzbühler model 8130 DUPLEX**. This equipment consisted of a $3.5 \mathrm{MHz}$ realtime scanner in combination with a $2 \mathrm{MHz}$ pulsed doppler. The realtime image and the doppler spectrum were displayed simultancously (sce figures 1 and 2). The angle between the doppler beam and the linear array was fixed at $50^{\circ}$. The flow measurements were evaluated off line from frozen images, in which the vessels' diameters were determined by focussing the respective area of measurement (see figures 1 and 2). The instrument calculated the flow velocity $(\mathrm{cm} / \mathrm{sec})$ and the corresponding blood flow volume $(\mathrm{ml} /$ $\mathrm{min}$ ) from the doppler spectrum over an adjustable time interval (i. g. one heart cycle).

Following the placement of the impedance electrode bands and taking the supine position, the patients were kept resting until reproducible measurements of maternal and fetal cardiac output could be obtained prior to hemodilution.

** Marketing: Squipp Medical Systems, Solingen, FRG

\subsection{Statistics}

Statistical analysis included the Student's t-test for paired observations. The correlation coefficients were calculated using the overall mean value per measurement.

\section{Results}

\subsection{Maternal hemodynamics}

Hypervolemic hemodilution with $500 \mathrm{ml}$ dextran induced an increase in cardiac index which was mainly due to elevated stroke volume. Beat-to-beat registration of isolated stroke volume revealed an increase from $69.9 \mathrm{ml}$ prior to infusion to $83.6 \mathrm{ml} 45$ minutes after the beginning of plasma volume expansion. In the following period up to 60 minutes post infusionem, both the cardiac index and the stroke volume slightly decreased but did not reach the respective values at rest prior to hypervolemic hemodilution. No remarkable changes in maternal heart rate and mean arterial blood pressure were found during the total period of investigation. In the course of normovolemic hemodilution with $0.9 \% \mathrm{NaCl}$ the intraindividual comparison for 
all parameters showed no statistically significant differences throughout the 120 minutes period.

Table II summarizes the mean values $(\overline{\mathbf{x}})$ and standard deviations (SD) for heart rate, stroke volume and cardiac index for both dextran and $\mathrm{NaCl}$ procedures.

\subsection{Fetal hemodynamics}

As an exemplary illustration figures 1 and 2 show the original recordings of doppler shifts

a)
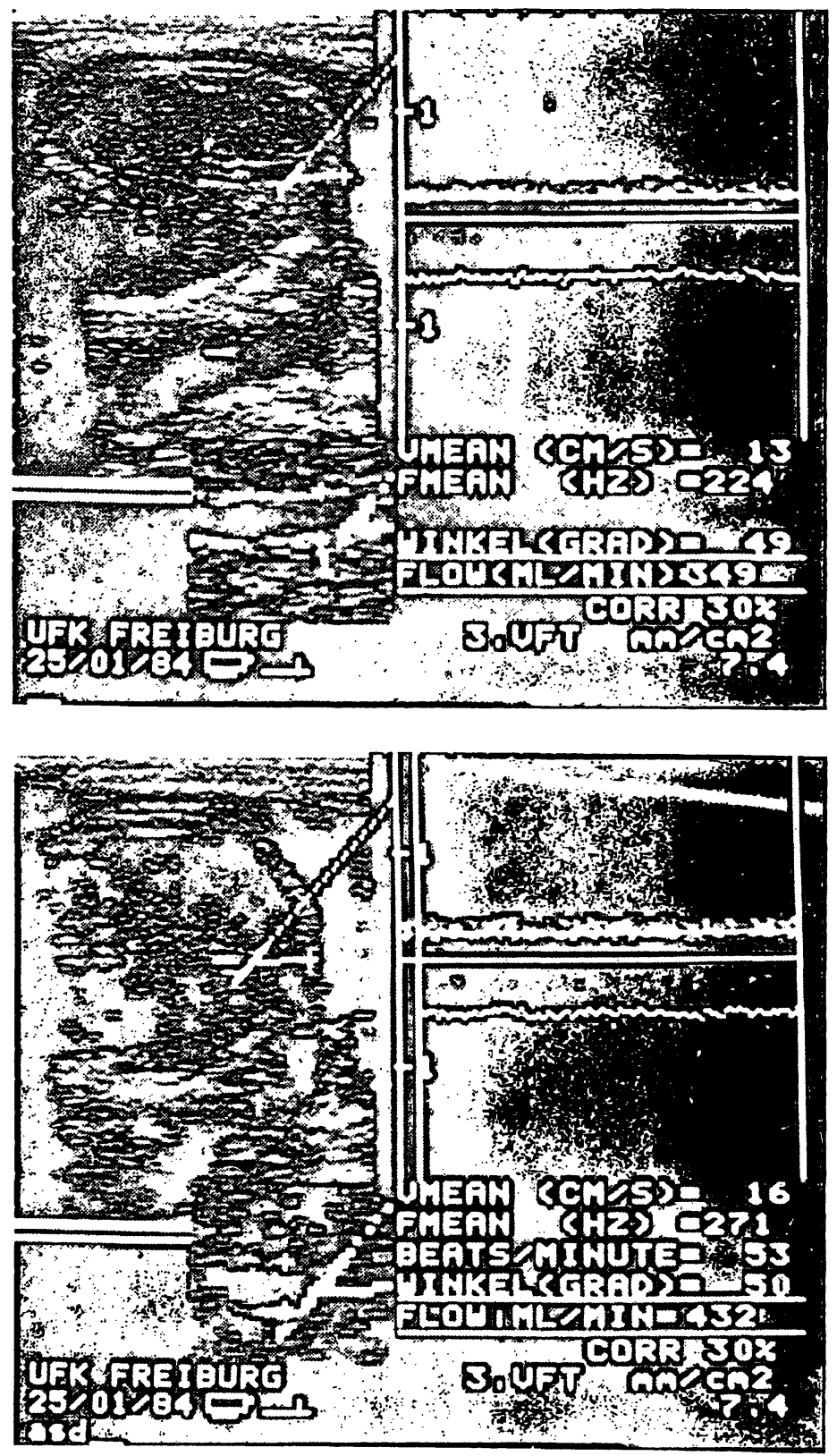

in case 3 (Pat. F. R.) at three different times during hypervolemic hemodilution: prior to infusion, 30 minutes after the beginning and finally 60 minutes after the end of dextran application.

In this case fetal blood flow parameters could be investigated in the descending aorta (figure 2) as well as in the umbilical vein (figure 1). The alterations in fetal hemodynamics in this patients are representive for our general experience in all cases. During hypervolemic hemodilution we found a significant increase in blood

b)

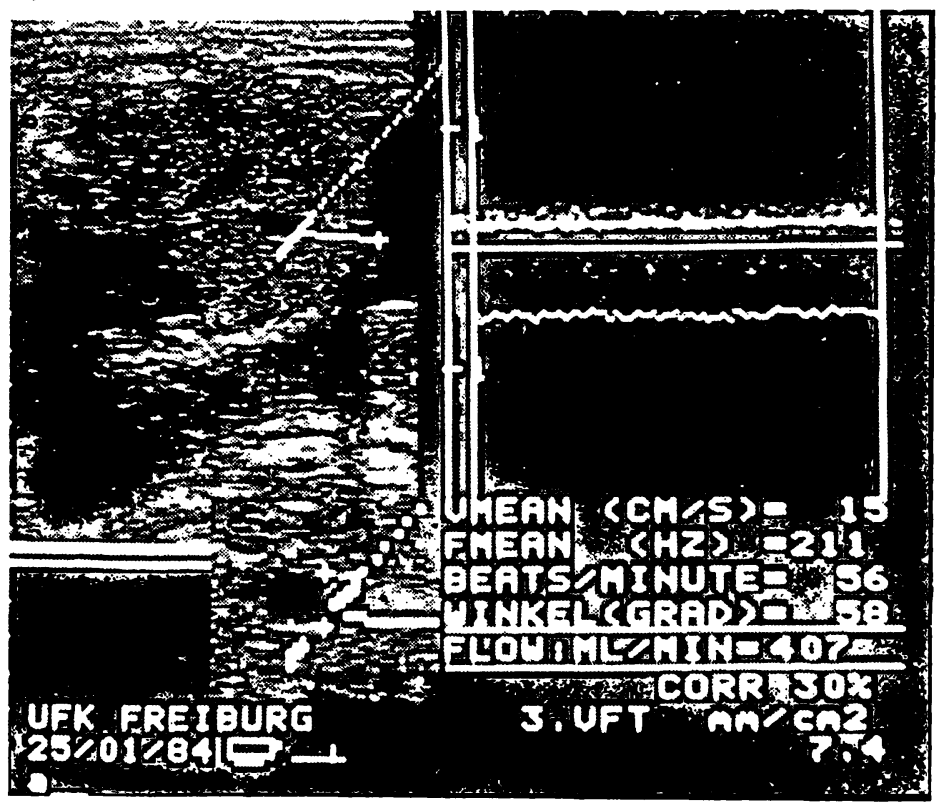

c)

Figure 1. Original tracing of doppler shift at a) time 0 (prior to infusion), b) time 30 during dextran application, c) time p 60 (60 minutes after dextran supply) in the fetal V. umbilicalis. 
velocity which was also evident within the follow-up period of 60 minutes after dextran supply. Aortic flow volume rose from $216 \mathrm{ml} / \mathrm{min}$, $\mathrm{kg}$ to $268 \mathrm{ml} / \mathrm{min}, \mathrm{kg}$ at time $\mathrm{p} 15$ and remained nearly unchanged till the end of observation.

During $\mathrm{NaCl}$ infusion no significant changes in fetal circulation could be exhibited. The results are summed up in Table III.

Figure 3 illustrates the percent changes in matcrnal cardiac index and fetal aortic flow volume $/ \mathrm{kg}$ body weight in comparison between dextran and $\mathrm{NaCl}$ supply. In the course of

a)

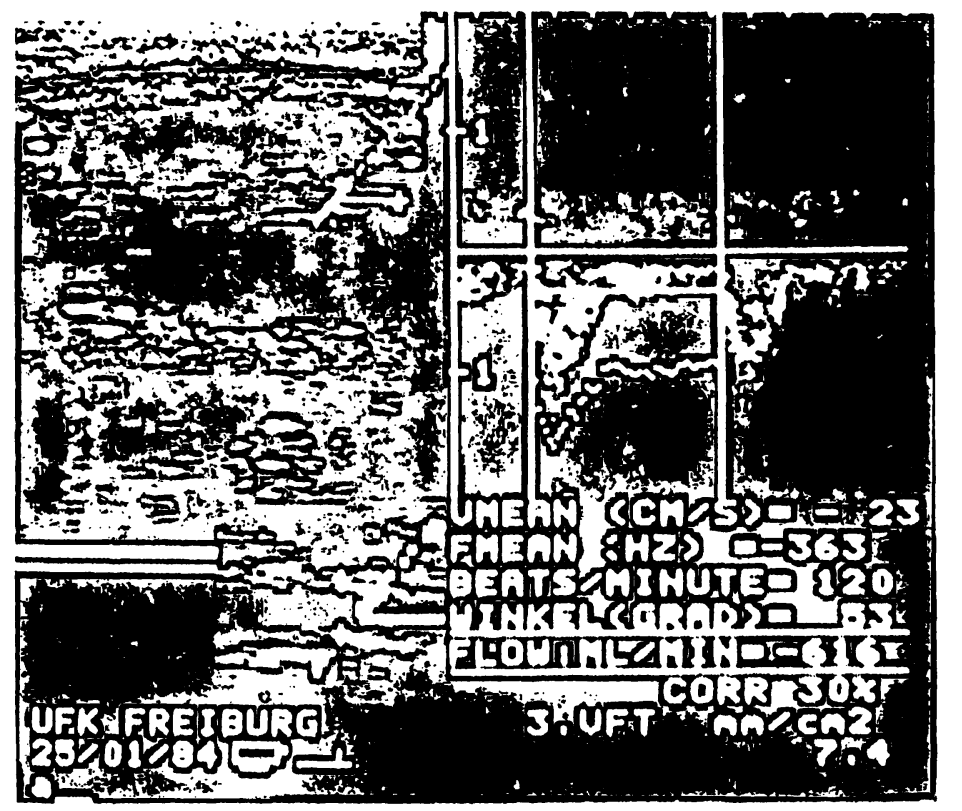

Figure 2. Original tracing of doppler shift at a) time 0 (prior to infusion), b) time 30 during dextran application, c) time p 60 (60 minutes after dextran supply) in the fetal $\mathrm{A}$. descendens. maternal plasma volume expansion both circulatory systems react with an increase in cardiac output. In fetal cardiovascular system this effect is maintained till 60 minutes after the cnd of dextran infusion ( $p 60$ ), whereas maternal cardiac output constantly decreases within $\mathrm{p} 15$ and $\mathrm{p} 60$.

Fetal blood flow velocity in the descending aorta and maternal cardiac index strongly correlate (figure 4) on the analysis of the mean values of both parameters during hypervolemic hemodilution.

b)

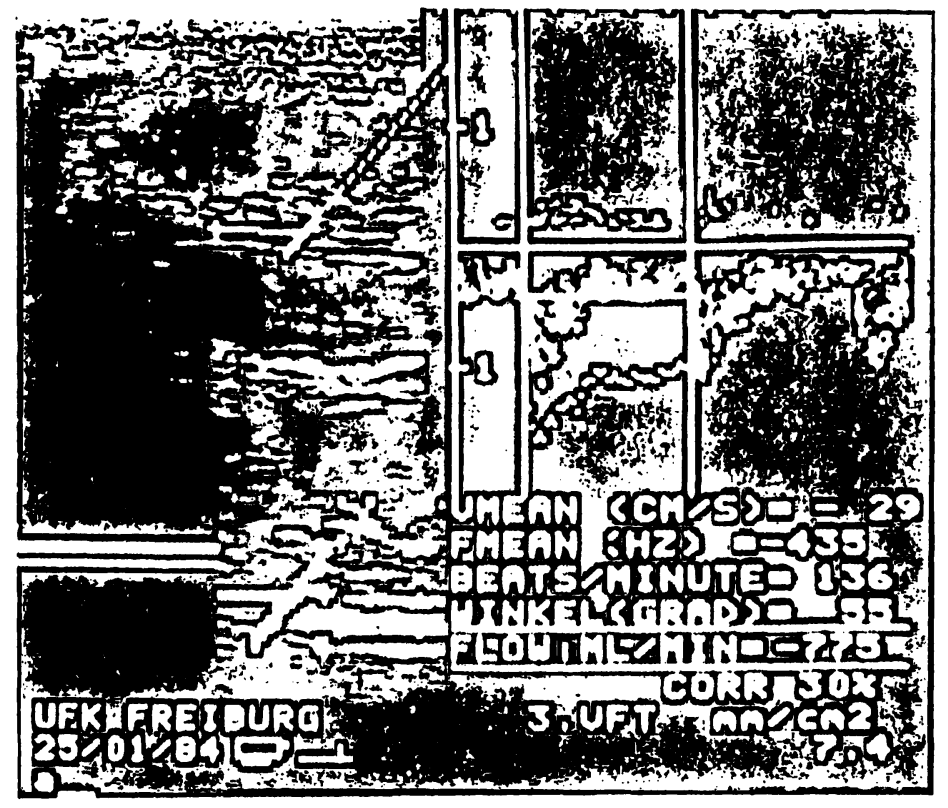

c)

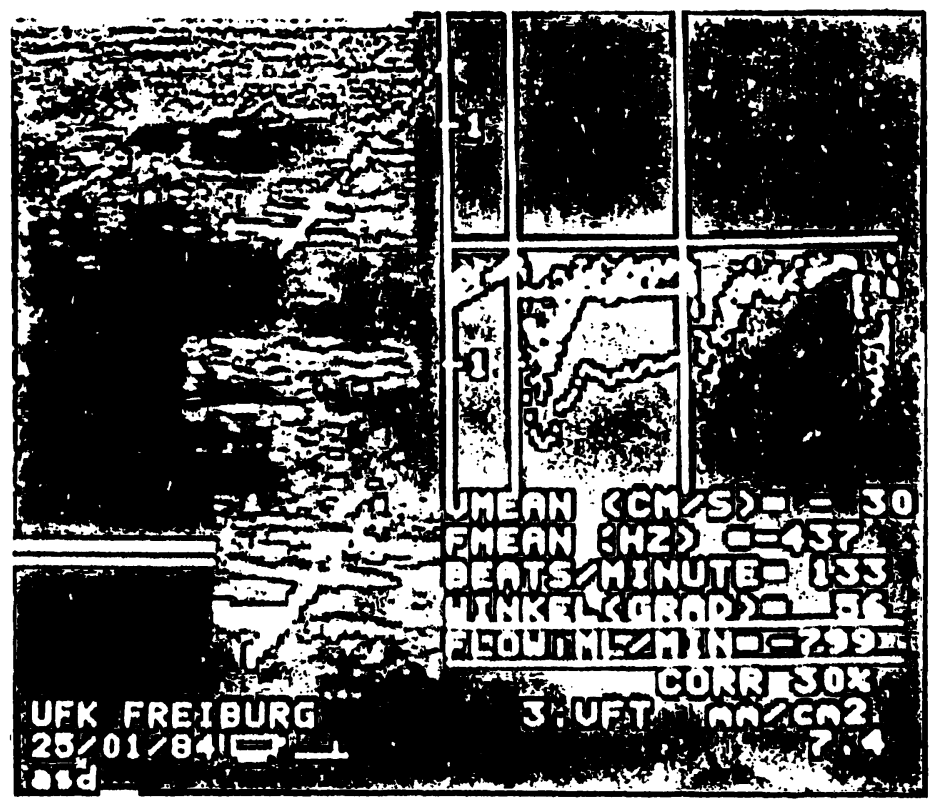


Table III. Summary of fetal hemodynamic parameters during dextran 40 and $\mathrm{NaCl}$ supply.

Mean values + standard deviation ( $), *=p<0.05$ (in relation to the respective value prior to infusion).

I. Dextran 40

\begin{tabular}{|c|c|c|c|c|c|c|c|c|}
\hline Parameter & $\begin{array}{l}\text { prior to } \\
\text { infusion }\end{array}$ & $\begin{array}{l}15 \\
\text { Time } \\
\text { (min) }\end{array}$ & 30 & 45 & 60 & p 15 & p 30 & $\mathrm{p} 60$ \\
\hline $\begin{array}{l}\text { Heart rate } \\
\text { (bts/min) }\end{array}$ & $127(7)$ & $131(8)$ & $* 137(10)$ & $136(14)$ & $140(12)$ & $136(6)$ & $134(5)$ & $133(4)$ \\
\hline $\begin{array}{l}\text { Flow velocity } \\
(\mathrm{cm} / \mathrm{sec})\end{array}$ & $22.8(3.9)$ & $25.2(3)$ & $* 28.0(3.2)$ & *27.1(4.5) & $* 27.2(5.2)$ & $* 28.8(2.8)$ & *27.6(2.9) & $* 28.8(3.6)$ \\
\hline
\end{tabular}

II. $\mathrm{NaCl}$

\begin{tabular}{lllllllll}
\hline $\begin{array}{l}\text { Heart rate } \\
\text { (bts/min) }\end{array}$ & $135(5)$ & $136(8)$ & $135(14)$ & $130(11)$ & $134(10)$ & $128(6)$ & $128(12)$ & $137(18)$ \\
$\begin{array}{l}\text { Flow velocity } \\
\text { (cm/sec) }\end{array}$ & $26.2(3.9)$ & $27.1(3)$ & $27.2(1.3)$ & $28.2(3.6)$ & $27.8(4)$ & $26.7(3.2)$ & $26.0(2.6)$ & $26.2(2.7)$ \\
$\begin{array}{l}\text { Aort. flow vol./ 243(43) } \\
\text { body weight } \\
\text { (ml/min, } \mathrm{kg})\end{array}$ & $251(44)$ & $252(36)$ & $257(35)$ & $250(23)$ & $245(33)$ & $236(28)$ & $243(35)$ \\
\hline
\end{tabular}

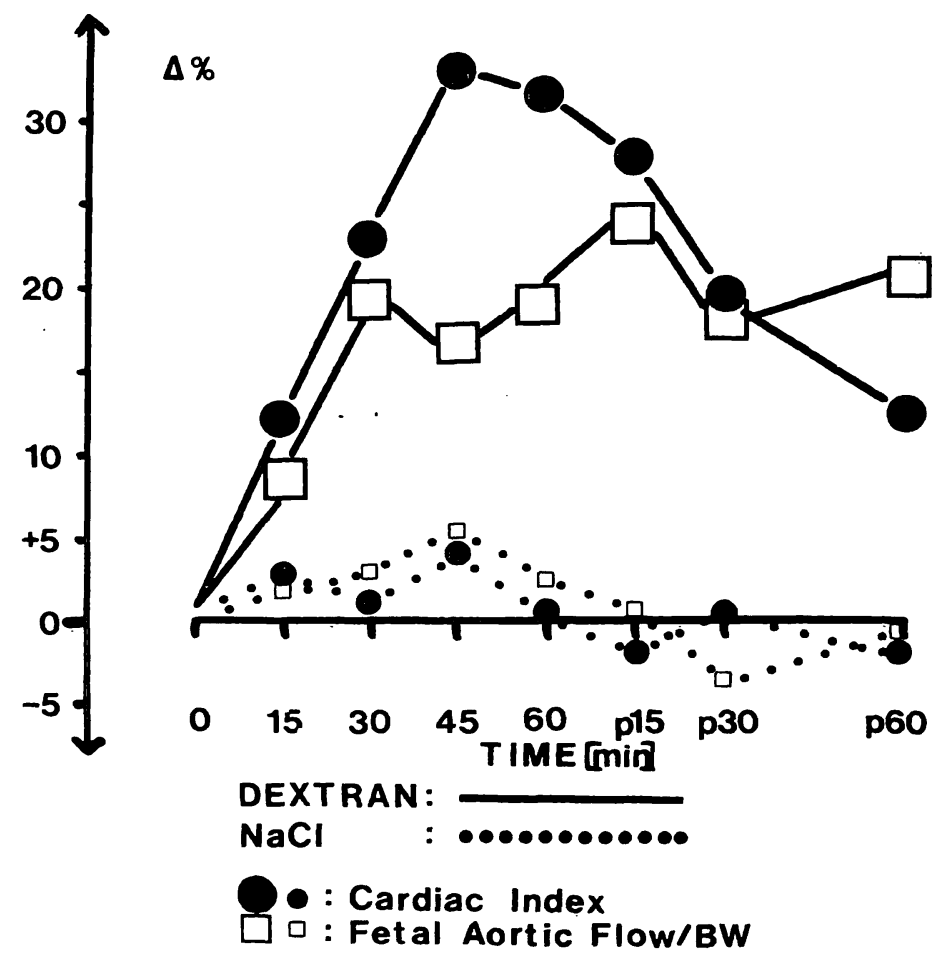

Figure 3. Percent changes of maternal and fetal hemodynamic parameters in the course of dextran and isotonoc $\mathrm{NaCl}$ supply.

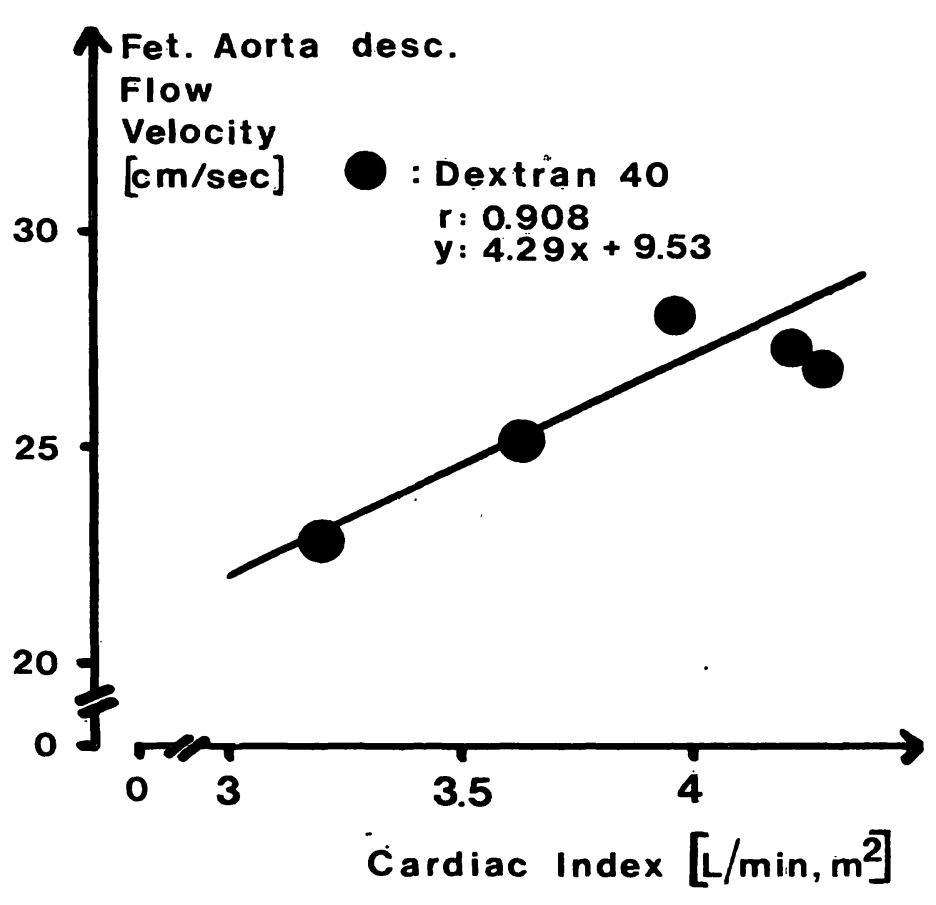

Figure 4. Correlation between maternal cardiac index and fetal blood flow velocity during hypervolemic hemodilution with dextran. 


\section{Discussion}

The objective of this study was to assess circulatory effects of hypervolemic hemodilution in pre-eclampsia for both mother and fetus. We used two noninvasive methods which so far were not combined until now. Both techniques - thoracic impedance cardiography and pulsed doppler/realtime transducer - are complementary and appear to be a promising approach for noninvasive estimation of maternal and fetal circulation. Thoracic impedance cardiography is easy to perform and particularly suited for the determination of changes in cardiac performance during a longtime period. This technique enables the interindividual study of circulatory effects of different therapeutic procedures such as fluid therapy. In previous studies [21] we estimated a correlation of $r=0.81$ in cardiac output between impedance cardiography and the thermodilution method using Swan-Ganz thermistor catheter.

Fetal blood flow measurements with pulsed doppler equipment maintain potential sources of errors, especially the correct determination of vessel diameter and the accuracy in finding the optimal angle between doppler beam and fetal vessel [3]. This study protocol was designed as an intraindividual longitudinal study; the individual vessel diameter remained constant within the whole period of investigation and the angle between doppler stream and vessel wall was in the range between $43^{\circ}$ and $63^{\circ}$ (mean: $53.1^{\circ} \pm 4.5^{\circ}$ ).

In pre-eclampsia, maternal hemodynamics are characterized by a lack of plasma volume expansion and a raised total peripheral resistance [8]. Elevated hematocrit is a good indicator of deficient plasma expansion [10]. In contrast to AssALI et al. [1] we support the opinion of GROENENDIJK et al. [8] that plasma expansion in pre-eclampsia is of potential benefits to maintain a normal cardiac index such as the physiological conditions in normal pregnancy. Hemodilution with oncotic active drugs also improves blood flow behavior in microcirculation [9].
In animal experiments SCHRÖCK et al. [17] investigated the influence of acute maternal hemodilution on pregnant ewe circulation. JoupPILA et al. [12] demonstrated nearly unchanged intervillous perfusion during albumin infusion. These results are in contrast to those from ScHWARZ et al. [19], which might be due to different alterations in maternal cardiac output between dextran 40 and albumin.

During hypervolemic hemodilution we estimated an increase in fetal blood flow velocity and flow volume in the umbilical vein and in the descending aorta. From these results it can be concluded that an elevated maternofetal fluid exchange could occur, although low molecular dextran does not pass the placenta [13].

In general, fluid exchange at the capillary level is determined by the oncotic and hydrostatic pressure gradients within the capillaries and the surrounding tissue fluids. These interactions also occur in the uteroplacental unit. According to the Hagen-Poiseuille law, vessel blood flow is determined by the pressure gradient and the vessel diameter. The regulation of blood volume between the fetus and the placenta is controlled by the different pressure gradients between placental blood flow and the umbilical vessels [16]. In cases of preeclampsia, BENEDETTI and CARLSON [2] described maternal colloidosmotic pressure to be significantly lower than in normotensive pregnancies. The normal range of maternofetal colloidosmotic pressure gradient is about $52 \mathrm{~mm} \mathrm{H}_{2} \mathrm{O}$ [17] and rises up to $92 \mathrm{~mm}$ $\mathrm{H}_{2} \mathrm{O}$ in cases with preeclampsia and intrauterine growth retardation [17]. In pregnant ewes, stepwise hypervolemic hemodilution with albumin leads to a slight fetal hemodilution, which can be identified by a further decrease in fetal colloidosmotic pressure [17]. The elevated hydrostatic intervillous pressure, induced by plasma volume expansion might be responsible for the net flow of water into the fetal circulation. Nevertheless improved blood flow properties in the course of plasma expander therapy may also play an additive role in the fetoplacental water transfer. Further studies are warranted to support these preliminary experiences. 
Siekmann et al., Maternal cardiac output and fetal blood flow in pre-eclampsia

\section{Summary}

In pre-eclampsia hemodynamic alterations are characterized by a lack of plasma volume expansion and a raised peripheral vascular resistance.

For the compensation of plasma volume deficit and to restitute blood fluidity the therapeutic use of plasma volume expanders (f. e. low molecular dextran) is recommended. Several groups (Goodurn et al. [6], CloEREN et al. [4], Heilmann et al. [9], Seghal et al. [20], SCHRÖCK [18]) have demonstrated benefitial effects on fetal status and development in the course of hypervolemic hemodilution in preeclampsia.

This therapeutic procedure presumes the continuous surveillance of maternal hemodynamics to early recognize heart insufficiency or fluid overload in the lungs. We use the noninvasive thoracic impedance cardiography for continuous monitoring of maternal heart performance.

The effect of hypervolemic hemodilution on fetal circulation has not been quantitatively investigated yet. Meanwhile pulsed doppler ultrasonography offers the possibility of estimating quantitative changes on fetal blood flow. We used both noninvasive techniques - thoracic impedance cardiography and pulsed doppler imaging system - for the simultaneous evaluation of maternal and fetal hemodynamic parameters during hypervolemic hemodilution.

This preliminary report summarizes the investigations in 5 patients with pre-eclampsia (mean arterial blood pressure $\geq 103.3 \mathrm{~mm} \mathrm{Hg}$, hemoconcentration with elevated hematocrit levels $\geq 38 \%$ ). The patients received an infusion of $500 \mathrm{ml}$ dextran 40 over a period of exactly 60 minutes. The simultaneous measurements of maternal and fetal cardiovascular parameters were performed in 15-minutes intervals during dextran application and 15 minutes ( $p 15), 30$ minutes ( $p 30$ ) and 60 minutes ( $p 60)$ after the end of infusion.

Twentyfour hours after dextran application the same patients received $500 \mathrm{ml}$ physiological saline infusion under the identical conditions to distinguish between dextran specific and nonspecific effects of maternal hemodilution in intraindividual comparison.

Results: Hypervolemic hemodilution with dextran 40 induced a significant increase in maternal cardiac index, the maximum values of cardiac index were registrated 45 minutes after the starting of infusion. In the following 60 minutes after the end of dextran supply cardiac index slightly decreased.

During the infusion of $500 \mathrm{ml} 0.9 \% \mathrm{NaCl}$ solution maternal cardiac index at all times remained nearly unchanged. Maternal heart rate and mean arterial blood pressure showed no remarkable alterations for both hemodilution regimen.

Fetal aortic blood flow velocity significantly increased during and after dextran application. Fetal aortic blood flow volume also showed a significant increase $(+20 \%)$ and remained elevated up to 60 minutes after the end of infusion. Original recordings of fetal doppler shifts (aorta descendens, vena umbilicalis) are giving evidence of the investigated data.

Fetal blood flow velocity in the descending aorta and maternal cardiac index strongly correlated $(r=0.908)$. In contrast during and after $\mathrm{NaCl}$ infusion no quantitative changes in fetal flow velocity and flow volume could be exhibited.

Discussion: These preliminary observations indicate that hypervolemic hemodilution in preeclampsia correlate with a rise in fetal blood flow velocity and flow volume. This fact might be due to elevated uteroplacental perfusion via raised maternal cardiac output. In intraindividual comparison normovolemic hemodilution do not demonstrate similar effects.

In accordance to animal studies (SCHRöCK, [17]) plasma volume expansion leads to elevated hydrostatic intervillous pressure, which might be responsible for the net flow of water into fetal circulation. Further studies are warranted to support these first experiences.

Keywords: Fetal blood flow characteristics, impedance cardiography, plasma volume expansion in preeclampsia, pulsed Doppler ultrasound.

\section{Zusammenfassung}

Simultane Vergleichsuntersuchungen zur maternalen und fetalen Herzauswurfleistung unter hypervolämischer Hämodilution bei der Präeklampsie - Erste Ergebnisse Die hämodynamischen Veränderungen bei der Präeklampsie sind durch eine fehlende Plasmavolumen-Expansion in Verbindung mit einem pathologisch gesteigerten peripheren Gefäßwiderstand gekennzeichnet.

Als rheologisch orientierte, die Fließeigenschaften des Blutes verbessernde Therapiemöglichkeiten bieten sich die parenterale Gabe von Plasmavolumenexpandern, z. B. niedermolekulares Dextran an. Von verschiedenen Arbeitsgruppen (GooduIN et al. [6]; CLOEREN et al. [4];
HeIlmanN et al. [9]; Seghal et al. [20]; SCHRÖCK [18]) ist der günstige Einfluß einer hypervolämischen Hämodilutionsbehandlung auf die fetale Entwicklung bei der Präeklampsie beschrieben worden.

Diese Therapie setzt jedoch die kontinuierliche kardiopulmonale Úberwachung der Mutter zur frühzeitigen Erkennung einer pulmonalen Überwässerung und einer insuffizienten Herzauswurfleistung voraus. $\mathrm{Zu}$ diesem Zweck führen wir eine Herz-Kreislaufüberwachung mit Hilfe der nichtinvasiven thorakalen Impedanzkardiographie durch.

Neben den Veränderungen im mütterlichen Herzkreis- 
laufsystem stellt dic fetale Zirkulation unter diesem therapeutischen Verfahren einen bisher noch nicht quantitativ crfaßten Parameter dar. Die Kombination von RealTime-Sonographic mit gepulsten Doppler-Systemen ermöglicht mittlerweile die quantitative Beurtcilung fetaler Flußgrößen über die Erfassung venöser und artericller Doppler-Geschwindigkeitsprofile. In Verbindung von thorakaler Impedanzkardiographie und gepulstem Doppler-Verfahren werden crstmals zwci nicht invasive Mcthoden kombiniert, um unter einer hypervolämischen Hämodilution sowohl die maternalc als auch fetale Hämodynamik erfassen zu können.

Diese Untersuchungen wurden bei 5 Patientinnen mit Präeklampsie (mittlerer arterieller Blutdruck $103.3 \mathrm{~mm}$ $\mathrm{Hg}$, Hämokonzentration mit Hkt-Werten $38 \%$ ) durchgeführt. $500 \mathrm{ml}$ Reomakrodex "wurde in exakt 60 Minuten parenteral appliziert, zusätzlich erfolgte nach Infusionsende in der anschließenden Stunde zu drei Meßzeitpunkten ( $\mathrm{p} 15, \mathrm{p} 30, \mathrm{p} 60$ ) die Kontrollmessung fetalcr und maternaler Kreislaufparameter. Innerhalb der Infusionszeit wurden die Messungen in 15-Minuten-Abständen durchgeführt.

24 Stunden nach hypervolämischer Hämodilution crfolgte bei den gleichen Patientinnen unter identischen Meßbedingungen cinc isovolämische Hämodilution mit $500 \mathrm{ml} \mathrm{NaCl}$ im Sinne eines plazebo-kontrollierten intraindividuellen Kreuzversuches. Damit sollten nicht dextranspezifische Einflüsse auf das mütterliche und fetale Herzkreislaufsystem verifiziert werden. Auf die Einhaltung einer reproduzierbaren Ruhemeßphase wurde in allen Untersuchungen entsprechend Wert gelegt.

Ergebnisse: Die hypervolämische Hämodilution mit Dextran 40 rührte zu einer signifikanten Zunahme der Herzauswurfleistung, die nach 45 Minuten ihr Maximum erreichte und nach Infusionsende innerhalb der einstündigen Kontrollpcriode allmählich wieder abfiel. Demgegenüber blieb der maternalc Herzindex während und nach $\mathrm{NaCl}-\mathrm{Infusion}$ nahezu unverändert. Mütterliche Herzfrequenz und mittlerer arterieller Blutdruck ergaben für die gesamte Meßzeit kcinc signifikanten Veränderungen.

Schlüssclwörter:

Fetale Blutflußmessungen, gepulster Doppler, hypervolämische Hämodilution. Impedanzkardiographie, Präeklampsie.
Die fetale aortale Flußgeschwindigkeit sticg unter Dextran-Gabe schncll an und blieb auch im Anschluß an die cinstündige Infusionszcit wcitcrhin crhöht; hingegen ließ sich unter $\mathrm{NaCl}-\mathrm{Infusion}$ keine signifikante Änderung dieses Parameters nachweisen.

Dic fetale aortale Herzauswurfleistung in Form des gewichtsbezogenen Flußvolumens stieg mit dem mütterlichen Herzindex innerhalb der ersten 30 Minuten unter Dextran nahezu parallel an. Im wciteren Verlauf bis zum Meßzeitpunkt p 60 crgab sich im fetalen Krcislauf cinc um $20 \%$ gegenüber dem Ausgangswert gesteigerte Auswurflcistung.

Anhand von Originalregistricrungen der Doppler-ShiftSignale aus der Aorta descendens und Vena umbilicalis unter hypervolämischer Hämodilution werden diese Verändcrungen belegt. Dic enge hämodynamische Beziehung beider Kreisläufe spiegelt sich in der lincaren Regression $(r=0.908)$ zwischen mütterlicher Herzauswurfleistung und fetaler aortaler Flußgeschwindigkeit wider.

Diskussion: Diese ersten Ergebnisse, dic mit Hilfe der Kombination zweier nichtinvasiver Verfahren die simultane Messung des mütterlichen und fetalen Herzkreislaufsystems gestattet, geben den Hinwcis, daß dic durch eine Plasmavolumenexpansion induzierte Verbesserung der uteroplazentaren Perfusion mit einer Erhöhung der fetalen Herzauswurfleistung korreliert. Unter der Infusion von physiologischer Kochsalzlösung gleichen Volumens läßt sich im intraindividuellen Vergleich dieser Efrekt nicht nachwcisen. Auch unter dem Vorbehalt des noch kleinen Stichprobenumfanges der hicr dargelegten Ergebnisse darf als vorläufiges Ergebnis festgestcllt werden, $\mathrm{da} B$ das Mehrangebot an intravasalem Volumen in Analogic zu ticrexperimentellen Untersuchungen von SCIIRÖCK [17] übcr cine Erhöhung des matcrnofetalen hydrostatischen Druckgradienten zu cinem in Richtung Fet rührenden Volumenaustausch mit entsprechender Erhöhung des fetalen Blutvolumens und der fetalen Blutströmungsgeschwindigkeit führt. Weitere Untcrsuchungen müssen diese ersten Erfahrungen untermauern.

\section{Résumé}

Les études simultanées sur les systèmes cardio-circulatoires feeteaux et maternels au cours de l'infusion hypervolémic aux cas des prééclampsies

Dans la prééclampsie, les changements hémodynamiques sont caractérisćs par un déficit du volume plasmatique associé à une ćlévation des résistances périphériques.

D'un point de vuc rhéologique, l'application parentérale de "plasma-expander», se présentc commc une des mcilleures thérapcutiques en vue de l'obtention d'une fluidité optimale sanguine. D'après diverses équipes de recherche, (Goodlin et co. [6]: Cl.oeren et co. [4]; HillmanN et co. [9]; Srgiıl et co. [20]; SCHKöck [18]) le traitement par hémodilution hypervolémique jouc un rôlc favorable sur le développement fatal dans la préćclampsic.

Cette therapic suppose cependant, une surveillance permanente cardio-pulmonairc de la mèrc pour détccter assez tôt les premiers signes d'aedème pulmonaire et d'insuffisance cardiaque. Dans cette optique, nous menons unc surveillance cardio-circulatoire grâce ḋ des moyens non-invasifs d'uimpédance cardiographic» thoracale.

A côté des changements dans le système cardio-circula- 
toire maternel, nous n'avons jusqu'à présent aucune valeur quantitative des variations du système circulatoire fœtal engendrées par ce procédé.

La combinaison de «Real-Time-Sonographie» et dú système Doppler a autorisé entretemps une appréciation quantitative des débits fœtaux grâce à la réalisation de profils de vitesse Doppler veineux et artériels. En parallèle avec l'impédance cardiographie thoracale et le principe du pouls «Doppler» seront d'abord combinées deux méthodes non-invasives, afin de pouvoir contrôler lors d'une hémolution hypervolémique tant l'hémodynamique maternelle que fotale.

Ces examens furent menés auprès de 5 patientes en prééclampsie (tension artérielle moyenne $>103,3 \mathrm{~mm}$ $\mathrm{Hg}$, hémoconcentration d'une valeur d'hématocrite > $38 \%$ ). $500 \mathrm{ml}$ de Rheomacrodex ${ }^{\circledR}$ furent appliqués par voie parentérale en-déans 60 minutes très exactement; de plus, dans les heures suivant cette infusion, nous 'avons établi à trois moments précis ( p 15, p 30, p 60) des mesures de contrôle des paramètres circulatoires fœtaux et maternels. Au cours de l'infusion, les mesures ont été effectuées toutes les 15 minutes. 24 heures après cette infusion hypervolémique, suivit chez ces mêmes patientes et avec des mêmes conditions de mesure, une hémodilution isovolémique à l'aide de $500 \mathrm{ml}$ de $\mathrm{NaCl}$ dans le but d'un essai de contrôle-placebo. Dans ce cas, les effets spécifiques occasionnés par les dextrans sur les systèmes cardio-circulatoires fœtaux et maternels ne seront pas observés.

Résultats: L'hémodilution hypervolémique avec du Dextran 40 conduit à une augmentation de débit cardiaque qui atteint son maximum après 45 minutes et après infusion diminue graduellement toutes les heures où on le contrôle. En contrepartie, l'index cardiaque maternel reste inchangé pendant et après perfusion d'une solution saline. Au moment de chacune de ces mesures, aucune variation significative de fréquence cardiaque et ce tension artérielle moyenne maternelles ne fut observée.
Le débit aortique fœtal s'éleva rapidement sous administration de dextran et demeura à la fin d'une heure d'infusion, par la suite élevé; par contre, aucune variation significative de ces paramètres ne fut prouvée sous infusion de $\mathrm{NaCl}$.

Le débit aortique fotal s'élèva parallèlement à l'index cardiaque maternel en l'espace des premières 30 minutes sous dextran. Il s'en suit, dans le système circulatoire fœtal, au temps de mesure p 60, une élévation de débit de $20 \%$ par rapport aux valeurs de départ.

Ces variations circulatoires sous hémodilution hypervolémique furent prouvées par enregistrements originaux par «Doppler-Shift-Signal» sur aorte descendante et veine ombilicale.

L'étroite relation hémodynamique entre les 2 systèmes circulatoires se reflète en une régression linéaire $(r=$ 0,908 ) entre débit cardiaque maternel et flux aortique fotal.

Discussion: Les premiers résultats, qui au moyen de la combinaison de deux procédés non invasifs réalisent une exploration simultanée des systèmes cardio-circulatoires fœtaux et maternels, prouvent qu'il existe une corrélation entre l'amélioration de la perfusion utéro-placentaire induite par «plasma-expander» et l'élévation du débit fœtal. Sous perfusion de mêmes quantités de solution saline physiologique, on ne peut observer les mêmes effets.

Tout en tenant compte du fait que ces résultats ont été observés sur un nombre limité de patientes, on peut conclure que l'administration en surplus de volume intravasal (en analogie aux expériences sur animaux de SCHRÖCK [17]) conduit à une élévation du gradient hydrostatique materno-fœtal en faveur du fœtus avec augmentation proportionnelle entre le volume échangé et l'élévations des volume et débit sanguins fœtaux. La poursuite des examens dans ce domaine doit confirmer ces premières expériences.

Mots-clés: Doppler, hemodilution hypervolémique, «impédanced cardiographie», mesures du flux de sang fœtal, prééclampsie.

\section{References}

[1] Assali, N. S., D. L. VAughn: Blood volume in preeclampsia: Fantasy and reality. Am. J. Obstet. Gynecol. 129 (1977) 355

[2] Benedetti, T., R. Carlson: Studies of colloid osmotic pressure on pregnancy-induced hypertension. Am. J. Obstet. Gynecol. 135 (1979) 308

[3] Campbell, S., J. Diaz-Recasens, D. R. Griffin: New Doppler technique for assessing uteroplacental blood flow. Lancet i (1983) 675

[4] Cloeren, S. E., T. H. Lippert, M. HinselmanN: Hypovolemia in toxemia in pregnancy: Plasma expander therapy with surveillance of central venous pressure. Arch. Gynaekol. 215 (1973) 123
[5] Gallery, E. D. M., S. N. Hunyor, A. Z. Györy: Plasma volume contraction: A significant factor in both pregnancy-associated hypertension (preeclampsia) and chronic hypertension in pregnancy. Q. J. Med. 192 (1979) 593

[6] Goodlin, R. C., D. B. Cotton, H. C. Haesslein: Severe edema-proteinuria-hypertension gestosis. Am. J. Obstet. Gynecol. 132 (1978) 595

[7] Goodlin, R. C., C. A. Dobry, J. C. Anderson, R. E. Woods, M. QuATFE: Clinical signs of plasma volume expansion during pregnancy. Am. J. Obstet. Gynecol. 145 (1983) 1001 
[8] Groenendijk, R., J. B. M. J. Trimbos, H. C. S. WALLENBURG: Hemodynamic measurements in preeclampsia: Preliminary observations. Am. J. Obstet. Gynecol. 150 (1984) 232

[9] Heilmann, L., U. Siekmann: Die hypervolämische Hämodilution bei der Präeklampsie. Infusionsther. Klin. Ernaehr. 10 (1983) 311

[10] HeilmanN, L., U. StekmanN, H. Schmid-SchöNBEIN, H. LUDWIG: Hemoconcentration and preeclampsia. Arch. Gynecol. 231 (1981) 7

[11] JouppILA, P., P. KIRKINEN: Umbilical vein blood flow as an indicator of fetal hypoxia. Br. J. Obstet. Gynaecol. 91 (1984) 107

[12] Jouppila, P., R. Jouppila, A. KoIvula: Albumin infusion does not alter the intervillous blood flow in severe pre-eclampsia. Acta Obstet. Gynecol. Scand. 62 (1983) 345

[13] Kivikoski, J., S. Lundbom, J. T. Airaksinen: The dextran concentration in the umbilical cord of a newborn infant. Acta Anaesth. scand. [Suppl.] 24 (1966) 33

[14] KLosA, W.: Noninvasive Messungen mit dem gepulsten Doppler-Verfahren in der fetoplazentaren Einheit. In: KAISER, R. (ed.): Klinische Forschung in der Gynäkologie und Geburtshilfe. Thieme, Stuttgart 1985

[15] KubiceK, W. G., F. J. Kottke, M. U. Ramos, R. P. Patterson, D. A. Witsoe, J. W. Labree, W. RemoLE, T. E. Langman, H. Schoening, J. T. GaramelLA: The Minnesota Impedance Cardiograph theory and applications. Biomed. Engng. 9 (1974) 410
[16] LINDERKamp, O.: Placental transfusion: Determinants and effects. Clin. Perinatol. 9 (1982) 559

[17] SCHRöCK, R.: Maternofetal water transfer during hemodilution procedures in preeclampsia. 4th World Congress of the ISSHIP, Amsterdam 1984

[18] Schröck, R., W. Heimisch, K. Gebhardt, N. MENDLER: Hemodilution as a therapeutic procedure in EPH-gestosis. Bibl. Haematol. 47 (1981) 86

[19] Schwarz, R., U. Retzke, K. D. Schwartz, B. PoTSCHWADEK: Hämodynamische Prophylaxe der drohenden intrauterinen Hypoxie. Zentralbl. Gynaekol. 95 (1973) 273

[20] Seghal, N. N., J. R. Hiti: Plasma volume expansion in the treatment of preeclampsia. Am. J. Obstet. Gynecol. 138 (1980) 165

[21] Sizkmann, U.: Die Hämodynamik bei der Präeklampsie. In: Kaulhausen, H., J. SCHNEIDER: Schwangerschaftsbedingte Hypertonie. Thieme, Stuttgart 1983

[22] Siekmann, U., L. Heilmann, H. Ludwig: The therapeutic value of plasma volume expansion in pregnancies with disturbed microcirculation. In: HeILMANN, L., P. C. BuChaN: Hcmorheological Disorders in Obstetrics and Neonatology. Schattauer, Stuttgart 1984

Received January 25, 1985. Revised July 2, 1985. Accepted July 9, 1985.

PD Dr. med. U. Siekmann

Dept. of Obstetrics and Gynecology University of Essen

Hufelandstr. 55

4300 Essen 1, Fed. Rep. Germany 
国畾。 Mandereycken

蛊, Meermotim

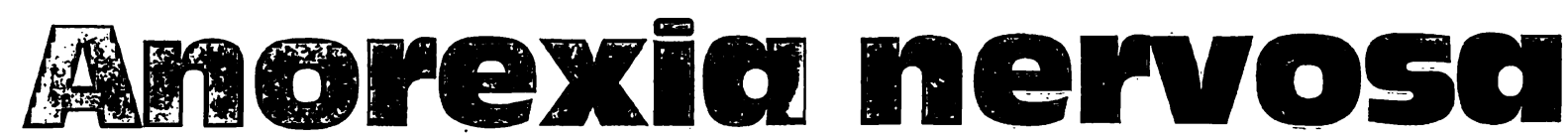

\section{A Clinician's Guide to Treatment}

1984. $17 \mathrm{~cm} \times 24 \mathrm{~cm}$. XIV, 251 pages.

Clothbound. DM 98,- ISBN 3110095319

Despite more than a century of ever-increasing scientific interest and research, anorexia nervosa - the pathological pursuit of thinness - still presents a challenge to clinicians throughout the world. It has become practically impossible to keep in touch with the constant proliferation of scientific literature on this subject. Moreover, the clinician (the general practitioner, the psychiatrist or the psychologist) needs, first and foremost, practical guidelines for his everyday therapeutic work with these patients.

Therefore, two experienced clinicians, who are daily involved in research and treatment of large numbers of anorexia nervosa patients, decided to write the first book dealing extensively with the many practical issues one is faced with when investigating and treating anorectic patients of all ages and in all stages of their illness. No single treatment modality, psychotherapeutic, pharmacologic or nutritional, has provided the final solution for the management of this intriguing syndrome. Hence, the therapeutic approach described in this book is characterized as an eclectic, broad spectrum or multimodal treatment in which strategies and interventions from different therapeutic models have been integrated.

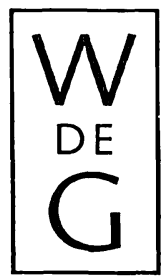

de Gruyter · Berlin · New York 